\title{
An Empirical Study on the Influence of Social Media on the Interpersonal Relationship of Middle School Students
}

\author{
Fancong Wang ${ }^{1}$ \\ Huayang Zhang ${ }^{2}$ \\ Xingyu Shi $^{3}$
}

\begin{abstract}
With the development of society, social media plays an increasingly important role in people's life as it creates a new social environment, which has subsequently and greatly changed the mode of communication in younger students. The new social norm will inevitably influence their interpersonal relationships and skills. The present study aims to find out the influence of social media on the interpersonal relationship of middle school students (including junior middle schools and senior middle schools). To this effect, 210 middle school students and 3 teachers from two middle schools in Guangzhou city of China took part in the research. Three aspects are considered in this study: interpersonal interaction (including interactions with peers, teachers, and strangers), interpersonal cognition (including an individual's evaluation of others, self-awareness, and selfpresentation) and social participation.
\end{abstract}

Keywords: Social Media, Middle School Students, Interpersonal interaction, Interpersonal cognition, Social participation.

\footnotetext{
${ }^{1}$ Ph.D. student, Faculty of Education, Beijing Normal University, China, e-mail: wang_fancong@qq.com.

${ }^{2}$ Ph.D. student, Faculty of Education, Beijing Normal University, China, e-mail: hasilly@126.com.

${ }^{3}$ Undergraduate, Business School, Beijing Normal University, China, e-mail: 827142846@qq.com.
} 


\section{Introduction}

With the development of society, social media plays an increasingly important role in people's daily life, which affects their life satisfaction, social trust and emotion (Zhao, 2014). The rapid development of social media has created a new social environment. The methods of communication have changed from face-to-face, letter and others in the past to virtual space, networks.

Interpersonal communication is an important part of individual social needs, and various interpersonal relationships have formed in the process of interpersonal communication (Wo et al., 2001). According to Ouyang (2000), interpersonal relationship is an important index to measure someone's psychological health. Having positive psychological qualities is one of the core literacy requirements for Chinese students (Lin, 2007). Many studies have shown that the quality of interpersonal has a significant effect on adolescents' social skills, psychological health and academic achievement. Good interpersonal relationships can promote adolescents' mental health, self-awareness and academic achievement (Ding et al., 2004).

In China, middle schools include junior middle schools and senior middle schools, of which junior middle schools include grades 7, 8, 9, and senior middle schools include grades 10, 11, 12. Middle school students nowadays are mostly the generation after 00s, who are digital natives. They grow up with digital technologies such as the Internet and mobile phones. However, middle school students are in a period of rapid development of physiology and psychology, and their physiological and psychological development characteristics will inevitably be reflected in their interpersonal communication (Wo et al., 2001). Therefore, the emergence of social media will have a significant influence on their interpersonal relationships. The quality of interpersonal relationships determines whether they can have a correct value orientation and healthy psychological development. What are the effects of social media on the interpersonal relationship of middle school students? How to give correct guidance to these students as to social media and help them to build proper interpersonal relationships? These questions are worth further research. 


\section{Literature review}

Human has obvious social attributes, which based on human sociality, that is, to achieve multiple relationships between individuals through practical activities. Compared with adults, the interpersonal relationship of middle school students is relatively simple, mainly including three kinds: parent-child relationship, peer relationship and teacher-student relationship (Zhang, 2016). The existing researches have mainly discussed the influence of interpersonal relationship on the individual growth of middle school students from two aspects of teacher-student relationship and peer relationship (Zeng, et al., 2010). Social media breaks the traditional social ties that rely on geography, blood, etc., and brings interpersonal communication into a new era. Whether during life experience or learning, communication with strangers has become very common. Therefore, some scholars believe that there should be another relationship: the relationship with strangers (Wo, Lin, Ma et al., 2001).

Antony Mayfield defines social media as a new type of online media that can give users a lot of space to participate. For social individuals, social media can promote users to participate in social activities ( $\mathrm{Ni}$ et al., 2016). Therefore, in the age of social media, interpersonal relationships should include a social participation relationship between individuals and society in addition to the relationship amongst individuals.

Social media can easily affect the three characteristics of adolescent development: social cognitive ability, self-concept and self-esteem, peer group relationships. Among them, social cognitive ability refers to the ability to understand and manage multi-source social information, including empathy, anticipation or perception of other people's responses, and assessing the status of individuals in social groups (Barbara. M. Newman, 2014). Therefore, the use of social media for interpersonal communication, in addition to interpersonal interaction and social participation, should also include the individual's self-awareness and self-presentation.

In this paper, the influence of social media on the interpersonal relationships of middle school students is considered in three aspects: interpersonal interaction, interpersonal cognition and social participation. Interpersonal interaction is the interaction between individuals, including interactions with peers, teachers and strangers; interpersonal cognition refers to an individual's evaluation of others, self-awareness, and self-presentation, such as publishing dynamics through social media, showing self, etc. ; Social participation refers to the individual's participation in social 
activities, that is, conscious and behavioural participation in economic, political, cultural, social work and other activities.

\section{Research design}

\subsection{Participants}

This study investigated 231 middle school students from two middle schools in Guangzhou, and interviewed three teachers. The three teachers come from different subjects and different positions, including the head teacher and the information technology subject teacher. The information technology teachers usually teach more classes and have a wide range of contact with students. They have a better understanding of the situation of the students in the whole school, and the head teacher, who is in charge of the class, has more contact with the students and has a deeper insight into the situation of the students. All participants in this study have experience of using social media.

\subsection{Research tools}

\section{(1) Questionnaires}

The questionnaire in this study includes two parts: (1) personal data, such as: gender, grade; (2) the influence of social media on interpersonal relationship (see appendix 1).

Based on the existing questionnaire of interpersonal relationship, this study designed a first draft of the questionnaire and revised it by two experts in the field of educational technology. The second part of the questionnaire is measured with a Likert five-point scale, in which 1 means strongly disagree, 2 means disagree, 3 means uncertain, 4 means agree, 5 means strongly agree. Before the implementation of the questionnaire survey, we randomly selected 37 middle school students for a pilot study, and found that the overall reliability alpha value of the second part of the questionnaire is 0.807 , indicating a high reliability; then according to the consistency test of each dimension, we modify the options with large differences, and finally determine the reliability and validity of the questionnaire after revision and improvement. 
"The influence of social media on interpersonal relationship" is mainly designed from three aspects: interpersonal interaction, interpersonal cognition, and social participation, including six dimensions and 16 questions. Among them, 1-7 are about interpersonal interaction (including the use of social media to communicate with peers, teachers, and strangers); 8-13 are about interpersonal cognition (the use of social media for self-presentation, the influence of social media on self-behaviour and evaluation of others); 14-16 are about social participation (the use of social media to participate in social activities). A total of 231 questionnaires were collected, among which 210 were valid and 21 were invalid, with an effective rate of $90.91 \%$. Among them, 114 are female, 96 are male, and the proportion of female and male is equal. The Respondents involve in all grades of middle school and have experience in using social media.

\section{(2) Interviews}

The interview questions are designed based on the structure of interpersonal relationships and the characteristics of interpersonal relationships among middle school students. The interview outline includes six semi-closed questions. The content of the interview involves the evaluation of social media, the current situation of middle school students using social media for communication, and teachers' attitudes (see appendix 2).

\section{Results}

\subsection{Analysis of questionnaire survey results}

(1) Description of the influence of social media on the interpersonal relationship of middle school students in various dimensions

Table 1 The influence of social media on the interpersonal relationship of middle school students

\begin{tabular}{|c|c|c|c|c|c|}
\hline & Dimension & Id & Title & & \\
\hline \multirow{4}{*}{$\begin{array}{c}\text { Interpersonal } \\
\text { interaction }\end{array}$} & \multirow{3}{*}{$\begin{array}{l}\text { 1. Using social } \\
\text { media to } \\
\text { communicate } \\
\text { with peers }\end{array}$} & 1 & $\begin{array}{l}\text { Social media is an important way to } \\
\text { communicate with friends and know their } \\
\text { dynamics. }\end{array}$ & 4.09 & \multirow{3}{*}{4.00} \\
\hline & & 2 & $\begin{array}{l}\text { The use of social media is an important way } \\
\text { to strengthen my relationships with my } \\
\text { classmates and friends. }\end{array}$ & 4.05 & \\
\hline & & 3 & $\begin{array}{l}\text { The use of social media can strengthen the } \\
\text { interpersonal relationship between me and } \\
\text { my peers. }\end{array}$ & 3.85 & \\
\hline & $\begin{array}{l}\text { 2. Using social } \\
\text { media to }\end{array}$ & 4 & $\begin{array}{l}\text { Social media is an important way to } \\
\text { strengthen my relationships with my }\end{array}$ & 2.76 & 2.50 \\
\hline
\end{tabular}




\begin{tabular}{|c|c|c|c|c|c|}
\hline & \multirow{2}{*}{$\begin{array}{l}\text { communicate } \\
\text { with teachers }\end{array}$} & & \multicolumn{2}{|l|}{ teachers. } & \\
\hline & & 5 & $\begin{array}{l}\text { I use social media to communicate with } \\
\text { unfamiliar teachers. }\end{array}$ & 2.25 & \\
\hline & \multirow{2}{*}{$\begin{array}{l}\text { 3. Using social } \\
\text { media to } \\
\text { communicate } \\
\text { with strangers }\end{array}$} & 6 & $\begin{array}{l}\text { I will contact strangers I know on social } \\
\text { media in real life. }\end{array}$ & 2.42 & \multirow[b]{2}{*}{2.35} \\
\hline & & 7 & $\begin{array}{l}\text { When I'm in a low mood or in trouble, I'll } \\
\text { talk to strangers I know on social media and } \\
\text { ask for help. }\end{array}$ & 2.28 & \\
\hline \multirow{6}{*}{$\begin{array}{l}\text { Interpersonal } \\
\text { cognition }\end{array}$} & \multirow{3}{*}{$\begin{array}{l}\text { 4. Social media } \\
\text { is used for self- } \\
\text { presentation }\end{array}$} & 8 & $\begin{array}{l}\text { I often use social media to express my mood } \\
\text { and life. }\end{array}$ & 3.50 & \multirow{3}{*}{3.33} \\
\hline & & 9 & $\begin{array}{l}\text { I often use social media to comment on } \\
\text { others' news and express myself. }\end{array}$ & 3.39 & \\
\hline & & 10 & $\begin{array}{l}\text { I often post and present myself through } \\
\text { social media. }\end{array}$ & 3.11 & \\
\hline & $\begin{array}{l}\text { 5. The } \\
\text { influence of }\end{array}$ & 11 & $\begin{array}{l}\text { Self-presentation and self-evaluation in } \\
\text { social media will influence my behavior in } \\
\text { real life. }\end{array}$ & 2.70 & \\
\hline & $\begin{array}{l}\text { social media on } \\
\text { self-behavior }\end{array}$ & 12 & $\begin{array}{l}\text { The evaluation of others in social media will } \\
\text { affect my behavior in real life. }\end{array}$ & 2.82 & 2.89 \\
\hline & $\begin{array}{l}\text { and evaluation } \\
\text { of others }\end{array}$ & 13 & $\begin{array}{l}\text { The different performance of others in social } \\
\text { media and real life will affect my evaluation } \\
\text { of others. }\end{array}$ & 3.15 & \\
\hline & 6. Using social & 14 & $\begin{array}{l}\text { The use of social media has strengthened my } \\
\text { attention to social hot spots and current } \\
\text { events. }\end{array}$ & 3.77 & \\
\hline participation & participate in & 15 & $\begin{array}{l}\text { I often use social media to express my views } \\
\text { on social affairs. }\end{array}$ & 2.86 & 3.10 \\
\hline & & 16 & $\begin{array}{l}\text { I often discuss social events with others } \\
\text { through social media. }\end{array}$ & 2.95 & \\
\hline
\end{tabular}


Social media has a greater influence on the communication between middle school students and their peers $(\mathrm{M}=4.00)$. The use of social media can promote and strengthen the communication amongst middle school students and their peers, because the original intention of most middle school students to use social media is to contact their classmates and friends (85.2\%).

The mean value of self-presentation and participation in social activities through social media is slightly higher than 3, which indicates that social media can partly influence middle school students to express, present themselves and participate in social activities.

The influence of social media on the interpersonal relationship of middle school students is not significant in three aspects $(\mathrm{M}<3)$. The use of social media to communicate with teachers $(\mathrm{M}=$ 2.50), the use of social media to communicate with strangers $(M=2.35)$, and the influence of social media on self-behavior and evaluation of others $(\mathrm{M}=2.89)$

(2) The influence of social media on the interpersonal relationship of middle school students of different genders

Table 2 The influence of social media on the interpersonal relationship of middle school students of different genders 1

\begin{tabular}{|c|c|c|c|c|c|c|}
\hline Gender & $\begin{array}{c}\text { Communicate } \\
\text { with peers }\end{array}$ & $\begin{array}{c}\text { Communicate } \\
\text { with teachers }\end{array}$ & $\begin{array}{c}\text { Communicate } \\
\text { with strangers }\end{array}$ & $\begin{array}{c}\text { self- } \\
\text { presentation }\end{array}$ & $\begin{array}{c}\text { Self } \\
\text { behavior } \\
\text { and } \\
\text { evaluation } \\
\text { of others }\end{array}$ & $\begin{array}{c}\text { Social } \\
\text { participation }\end{array}$ \\
\hline Male & 3.99 & 2.70 & 2.48 & 3.22 & 2.98 & 3.27 \\
\hline Female & 4.00 & 2.34 & 2.24 & 3.44 & 2.82 & 3.13 \\
\hline
\end{tabular}

The influence of social media on the interpersonal relationship of middle school students of different genders is not significant. Table 2 The influence of social media on the interpersonal relationship of middle school students of different genders 1 In terms of self-presentation on social media, the mean value of female students is slightly higher than that of male students. In terms of using social media to communicate with teachers, strangers, self-behaviour, evaluation of others and social participation, the mean rate of male students is higher than that of female students. 
To analyse whether there is a significant difference in the influence of social media on interpersonal relationship among middle school students of different genders, we conducted the t-test (as shown in Table 3).

Table 3 T-test of the influence of social media on interpersonal relationship among middle school students of different genders2

\begin{tabular}{|c|c|c|c|c|c|c|c|}
\hline & \multicolumn{2}{|c|}{$\begin{array}{c}\text { Levene test of } \\
\text { variance equation }\end{array}$} & \multicolumn{4}{|c|}{ T-test for the mean equation } \\
\hline & & $\mathrm{F}$ & Sig. & $\mathrm{t}$ & $\mathrm{df}$ & $\begin{array}{c}\text { Sig. } \\
\text { (double } \\
\text { side) }\end{array}$ & $\begin{array}{l}\text { The mean } \\
\text { difference }\end{array}$ \\
\hline \multirow{2}{*}{$\begin{array}{l}\text { Using social media to } \\
\text { communicate with } \\
\text { peers }\end{array}$} & $\begin{array}{l}\text { Assuming equal } \\
\text { variances }\end{array}$ & 1.294 & .257 & .154 & 208 & .878 & .01645 \\
\hline & $\begin{array}{l}\text { Assuming } \\
\text { variances are } \\
\text { not equal }\end{array}$ & & & .152 & 192.830 & .879 & .01645 \\
\hline \multirow{2}{*}{$\begin{array}{l}\text { Using social media to } \\
\text { communicate with } \\
\text { teachers }\end{array}$} & $\begin{array}{l}\text { Assuming equal } \\
\text { variances }\end{array}$ & 3.137 & .078 & 3.021 & 208 & .003 & -.36541 \\
\hline & $\begin{array}{l}\text { Assuming } \\
\text { variances are } \\
\text { not equal }\end{array}$ & & & 2.983 & 188.729 & .003 & -.36541 \\
\hline \multirow{2}{*}{$\begin{array}{l}\text { Using social media to } \\
\text { communicate with } \\
\text { strangers }\end{array}$} & $\begin{array}{l}\text { Assuming equal } \\
\text { variances }\end{array}$ & 2.330 & .128 & 1.563 & 208 & .120 & -.24315 \\
\hline & \begin{tabular}{|l} 
Assuming \\
variances are \\
not equal
\end{tabular} & & & 1.548 & 192.768 & .123 & -.24315 \\
\hline \multirow{2}{*}{$\begin{array}{l}\text { Social media is used } \\
\text { for self-presentation }\end{array}$} & $\begin{array}{l}\text { Assuming equal } \\
\text { variances }\end{array}$ & 2.151 & .144 & 1.808 & 208 & .072 & .22037 \\
\hline & \begin{tabular}{|l} 
Assuming \\
variances are \\
not equal
\end{tabular} & & & 1.829 & 207.669 & .069 & .22037 \\
\hline \multirow{2}{*}{$\begin{array}{l}\text { The influence of social } \\
\text { media on self- } \\
\text { behaviour and } \\
\text { evaluation of others }\end{array}$} & $\begin{array}{l}\text { Assuming equal } \\
\text { variances }\end{array}$ & 384. & .536 & 1.360 & 208 & .175 & -.15720 \\
\hline & \begin{tabular}{|l} 
Assuming \\
variances are \\
not equal
\end{tabular} & & & 1.366 & 204.620 & .174 & -.15720 \\
\hline
\end{tabular}




\begin{tabular}{|l|l|r|r|r|r|r|r|}
\hline Using social media to & $\begin{array}{l}\text { Assuming equal } \\
\text { variances }\end{array}$ & 259. & .612 & 1.123 & 208 & .263 & -.13859 \\
\cline { 2 - 6 } $\begin{array}{l}\text { participate in social } \\
\text { activities }\end{array}$ & $\begin{array}{l}\text { Assuming } \\
\text { variances are } \\
\text { not equal }\end{array}$ & & 1.129 & 205.231 & .260 & -.13859 \\
\hline
\end{tabular}

Table 3 T-test of the influence of social media on interpersonal relationship among middle school students of different genders2The results show that the two-sided test Sig. value of using social media to communicate with teachers is 0.003 , and the value is less than 0.05 , which indicates that there is a significant difference between different genders in using social media to communicate with teachers, and social media promotes and strengthens communication between boys $(\mathrm{M}=2.70)$ and teachers in middle school more significantly than girls $(\mathrm{M}=2.34)$. In the other five dimensions, the Sig. values are greater than 0.05 , and the influence is not significant.

(3) The influence of social media on interpersonal relationship of middle school students in different grades

Table 4 The influence of social media on the interpersonal relationship of middle school students in different grades 3

\begin{tabular}{|c|c|c|c|c|c|c|}
\hline Grade & $\begin{array}{c}\text { Communicate } \\
\text { with peers }\end{array}$ & $\begin{array}{c}\text { Communicate } \\
\text { with teachers }\end{array}$ & $\begin{array}{c}\text { Communicate } \\
\text { with strangers }\end{array}$ & $\begin{array}{c}\text { Self- } \\
\text { presentation } \\
\text { behavior } \\
\text { and } \\
\text { evaluation } \\
\text { of others }\end{array}$ & $\begin{array}{c}\text { Social } \\
\text { participation }\end{array}$ \\
\hline 7 & 4.00 & 2.77 & 2.36 & 3.51 & 2.67 & 3.43 \\
\hline 8 & 3.82 & 2.58 & 2.28 & 3.35 & 2.94 & 3.26 \\
\hline 9 & 3.91 & 2.23 & 2.73 & 3.55 & 3.36 & 3.19 \\
\hline 10 & 4.00 & 2.39 & 2.25 & 3.12 & 2.78 & 3.04 \\
\hline 12 & 4.31 & 2.44 & 2.38 & 3.50 & 2.60 & 3.04 \\
\hline
\end{tabular}

As shown in

Table 4, except for the influence of social media on the self-behaviour and evaluation of others, there is no significant difference in other grades. 
To analyse whether there is a significant difference in the influence of social media on the interpersonal relationship of middle school students in different grades, we conducted a one-way ANOVA with "grade" as the factor, as shown in

Table 5.

Table 5 The difference test of social media influence on interpersonal relationship of middle school students in different grades (part)4

\begin{tabular}{|c|c|c|c|c|c|c|}
\hline Dependent variable & & (I) Grade & (J) Grade & $\begin{array}{l}\text { The mean } \\
\text { difference } \\
(\mathrm{I}-\mathrm{J})\end{array}$ & $\begin{array}{l}\text { Standard } \\
\text { error }\end{array}$ & $\mathrm{p}$-value \\
\hline \multirow{5}{*}{$\begin{array}{l}\text { Using social media to communicate } \\
\text { with teachers }\end{array}$} & \multirow[t]{5}{*}{ LSD } & \multirow[t]{5}{*}{7} & 8 & .18750 & .24316 & .442 \\
\hline & & & 9 & $.54006^{*}$ & .21423 & .012 \\
\hline & & & 10 & $.38260^{*}$ & .15885 & .017 \\
\hline & & & 11 & .33333 & .25398 & .191 \\
\hline & & & 12 & .03554 & .24831 & .886 \\
\hline \multirow{5}{*}{$\begin{array}{l}\text { Social media is used for self- } \\
\text { presentation }\end{array}$} & \multirow{5}{*}{ LSD } & \multirow[t]{5}{*}{10} & 7 & $-.38962^{*}$ & .15804 & .015 \\
\hline & & & 8 & -23378 & .22711 & .305 \\
\hline & & & 9 & $-.43404^{*}$ & .19617 & .028 \\
\hline & & & 11 & -.38087 & .23854 & .112 \\
\hline & & & 12 & -31271 & .23256 & .180 \\
\hline \multirow{10}{*}{$\begin{array}{l}\text { The influence of social media on } \\
\text { self-behavior and evaluation of } \\
\text { others }\end{array}$} & \multirow{10}{*}{ LSD } & \multirow[t]{5}{*}{9} & 7 & $.68468^{*}$ & .19352 & .000 \\
\hline & & & 8 & .41440 & .24368 & .091 \\
\hline & & & 10 & $.57402^{*}$ & .17811 & .001 \\
\hline & & & 11 & $.75447^{*}$ & .25252 & .003 \\
\hline & & & 12 & -.17057 & .24788 & .492 \\
\hline & & \multirow[t]{5}{*}{12} & 7 & $.85525^{*}$ & .22430 & .000 \\
\hline & & & 8 & $.58497^{*}$ & .26877 & .031 \\
\hline & & & 9 & .17057 & .24788 & .492 \\
\hline & & & 10 & $.74459^{*}$ & .21114 & .001 \\
\hline & & & 11 & $.92504^{*}$ & .27681 & .001 \\
\hline \multirow{5}{*}{$\begin{array}{l}\text { Using social media to participate in } \\
\text { social activities }\end{array}$} & \multirow[t]{5}{*}{ LSD } & \multirow[t]{5}{*}{7} & 8 & .17097 & .24497 & .486 \\
\hline & & & 9 & .23888 & .21583 & .270 \\
\hline & & & 10 & $.39512^{*}$ & .16003 & .014 \\
\hline & & & 11 & .38854 & .25587 & .130 \\
\hline & & & 12 & .05806 & .25016 & .817 \\
\hline
\end{tabular}

The LSD test shows that there is a significant difference between seventh graders, ninth graders and tenth graders in using social media to communicate with teachers. Social media promotes and 
strengthens the communication between seventh graders $(M=2.77)$ and teachers more significantly than ninth graders $(M=2.23)$ and tenth graders $(M=2.39)$.

In terms of the use of social media for self-presentation, there is a significant difference between tenth graders, seventh graders and ninth graders. Compared with seventh graders $(\mathrm{M}=3.51)$ and ninth graders $(M=3.55)$, tenth graders $(M=3.12)$ use social media to present themselves less frequently.

In terms of the influence of social media on self-behaviour and evaluation of others, there is a significant difference between ninth graders and seventh graders, tenth graders, eleventh graders, and there is also a significant difference between twelfth graders and seventh graders, eighth graders, tenth graders, eleventh graders. Ninth graders $(M=3.36)$ are more likely to be influenced by social media compared to seventh graders $(M=2.67)$, tenth graders $(M=2.78)$, and eleventh graders $(M=2.60)$ on self-behaviour and others' evaluation. Compared to seventh graders $(M=2.67)$, eighth graders $(M=2.94)$, tenth graders $(M=2.78)$, and eleventh graders $(M=2.60)$, twelfth graders $(\mathrm{M}=3.53)$ are more likely to be influenced by social media on self-behaviour and others' evaluation. In terms of using social media to participate in social activities, there is a significant difference between seventh graders and tenth graders. Seventh graders $(M=3.43)$ are more likely to use social media to participate in social activities than tenth graders $(\mathrm{M}=3.04)$.

\subsection{Analysis of the interview results of teachers}

(1) Teachers' evaluation of social media

Teachers tend to take a positive attitude towards middle school students' use of social media. They believe that social media can be widely used in life and learning. Because social media has the advantages of low cost, convenient communication, and strong interaction, it will become a trend for the whole people to widely use social media. In this environment, the use of social media can promote timely interaction between teachers and students, and help to establish a good relationship between teachers and students. But some teachers say that using social media to communicate with students will extend their working hours and take up rest time. 
(2) The current situation of the use of social media for teachers to communicate with students According to the interview results, teachers and students communicate less through social media. On the one hand, schools don't advocate the use of social media for communication; on the other hand, although teachers hold a positive attitude towards the use of social media, some teachers still say they will not use social media to communicate with students, and only occasionally provide some learning resources for students. Besides, teachers and students are less aware of the use of social media for communication. At present, teachers often send good learning resources to students through social media, but this is a one-way transmission of information. The better situation is that teachers use social media to solve the problems raised by their classmates, which is very rare. However, On a formal occasion or informing important things, teachers tend to choose the telephone and face-to-face.

(3) The evaluation of the influence of middle school students' use of social media on teacher-student relationship

Compared with traditional face-to-face communication, some students tend to use social media to communicate with teachers, and also actively want to communicate with teachers through social media. For example, a teacher said, "after teaching the content of e-mail, I posted my email on the blackboard, and when students encounter problems, they will send me an email.". Through social media, students can speak to teachers more directly, which makes their relationship closer. However, students are curious about teachers, and they will use social media to mine some personal information about teachers. 


\section{Discussion and conclusion}

\subsection{The influence of social media on the interpersonal interaction of middle school students}

Interpersonal interactions include interactions between individuals and peers, teachers, and strangers. Middle school students use social media to communicate more with peers $(M=4.00)$, but less with teachers $(M=2.50)$ and with strangers $(M=2.35)$, because most middle school students use social media to contact classmates and friends, and students and teachers have less initiative to communicate outside of class. In psychology, the rapid physical maturity of middle school students makes them have a strong sense of adulthood, hoping to make decisions like adults. However, teachers still regard them as children and limit them too much in learning, which makes them reluctant to communicate with teachers, and the relationship with teachers is weakened (Wo, Lin, Ma, etc., 2001). For teachers, although some teachers hold a positive attitude towards the use of social media, they think that it will extend their working hours and take up their rest time, so some teachers seldom use social media to communicate with students. Relevant researches have also shown that teachers recognize the significance of teacher-student communication after class, but do not act well ( $\mathrm{Li}, 2014)$. Besides, although the equal relationship between teachers and students is advocated, there is still a concept of "honor the teacher and respect his teaching" in China, which emphasizes the authority of teachers, and this unequal teaching relationship is easy to be generalized in real life, which affects the equal communication between teachers and students in society (Cong, 2005).

For middle school students of different genders, there is a significant difference in the use of social media to communicate with teachers. Social media promotes and strengthens communication between male students $(\mathrm{M}=2.70)$ and teachers in middle schools more than female students $(\mathrm{M}=$ 2.34). But generally speaking, middle school students use social media to communicate with teachers infrequently. For different grades, there is a significant difference between seventh graders, ninth graders, and tenth graders in using social media to communicate with teachers. Social media promotes and strengthens the communication between seventh graders $(M=2.77)$ and teachers more significantly than ninth graders $(M=2.23)$ and tenth graders $(M=2.39)$. Relevant researches have also shown that the quality of teacher-student relationship is the best for seventh graders (Yao, Tang, 2005). 


\subsection{The influence of social media on the interpersonal cognition of middle school students}

Interpersonal cognition includes self-presentation and the influence of social media on selfbehaviour and evaluation of others. To a certain extent, social media will affect middle school students' use of social media to express and present themselves. Middle school students use social media to express their views, post dynamics, and show themselves more frequently. Middle school students are mostly in adolescence and have a strong psychological need for identity, and the positive feedback of self-presentation on social media can promote adolescents' self-identity (Liu, Sun, Zhou, etc., 2015), which can also encourage middle school students to use social media to present themselves, get feedback from others, and then get a sense of self-identity. However, different grades of middle school students use social media to present themselves differently. There is a significant difference between tenth graders, seventh graders and ninth graders. Compared with seventh graders $(M=3.51)$ and ninth graders $(M=3.55)$, tenth graders $(M=3.12)$ use social media to present themselves less frequently. Some studies have shown that the self-identity level of senior middle school students is slightly higher than that of junior middle school students (Liu, Sun, Zhou, et al., 2015), and junior middle school students improve their self-identity through self-presentation of social media. In addition, in the interview, some teachers said that the school does not advocate the use of social media. For senior middle school students, most of them are forbidden to use mobile phones on campus, which may also lead to senior middle school students use social media to publish dynamic information and present themselves less frequently than junior middle school students.

On the other hand, social media has little effect on the self-behaviour of middle school students and the evaluation of others, but it is different for different grades. There is a significant difference between ninth graders and seventh graders, tenth graders, eleventh graders, and there is also a significant difference between twelfth graders and seventh graders, eighth graders, tenth graders, eleventh graders. Ninth graders $(M=3.36)$ are more likely to be influenced by social media compared to seventh graders $(M=2.67)$, tenth graders $(M=2.78)$, and eleventh graders $(M=2.60)$ on self-behaviour and others' evaluation. Compared to seventh graders $(M=2.67)$, eighth graders $(M=2.94)$, tenth graders $(M=2.78)$, and eleventh graders $(M=2.60)$, twelfth graders $(M=3.53)$ are more likely to be influenced by social media on self-behaviour and others' evaluation. Facing middle school and college entrance examinations, ninth graders and twelfth graders tend to have greater psychological pressure, which is easy to cause anxiety and mood fluctuation. (Xiao, Zhang, 
2016). Therefore, the behaviour of others on social media is more likely to cause changes in selfbehaviour and the evaluation of others.

\subsection{The influence of social media on middle school students' social participation}

Middle school students are more willing to use social media to focus on social activities (M = 3.77), but they are less likely to express their opinions $(\mathrm{M}=2.86)$ and discuss with others $(\mathrm{M}=$ 2.95). Some studies have also shown that most participants are reluctant to share their knowledge and views (Cabrera Á, Cabrera E F, 2002; ridings C, Gefen D, Arinze B, 2006). For students of different grades, there is a significant difference between seventh graders and tenth graders. Seventh graders $(M=3.43)$ are more likely to use social media to participate in social activities than tenth graders $(\mathrm{M}=3.04)$.

In addition, through interviews and questionnaires, it is found that some teachers also believe that social media can promote timely interaction between teachers and students, which is conducive to the establishment of good teacher-student relationships, but at present schools do not advocate the use of social media. 


\section{References}

Barbara. M. Newman. (2014). Social Media Influences Peer Relationship: Friendship, Loneliness and Sense of Belonging. China Youth Study, (2), 16-20.

Cabrera Á, Cabrera E F. (2002). Knowledge-sharing Dilemmas. Organization Studies, 23(5):687710.

Cong Lixin. (2005). Equal And Leading: Two Perspectives of Teacher-student Relationship. Journal of Educational Studies, 1(1):27-31.

Ding Zhaoye, Li Shouxin, Li Junchun. Correlation Analysis of Mental Health, Interpersonal Relationship and Academic Achievemen of Junior Middle School Students. Contemporary Educational Science, (19), 47-48.

Li Xincui. (2014). A Survey of Extracurricular Communication Between Teachers And Students in Junior High School. Moral Education China, (13):10-13.

Lin Chongde. (2017). The Research of Core Competencies and Values for Students in China. Studies of Psychology and Behavior, 15(2):145-154.

Liu Qingqi, Sun Xiaojun, Zhou Zongku, Niu Gengfeng. (2015). Self-presentation on Social Network Sites and Ego Identity: Mediation of Online Positive Feedback. Chinese Journal of Clinical Psychology, 23(6):1094-1097.

Ni Ning, Xu Zhi, Yang Liming. (2016). Complicated Users: A Research of Users' Participation Behavior in Social Media Advertising. Chinese Journal of Journalism \& Communication, (10):111-127.

Ouyang Wenzhen. (2000). Influence of Interpersonal Relationship Training on Mental Health of Undergraduates. Chinese Mental Health Journal, 21(3):186-187.

Ridings C, Gefen D, Arinze B. (2006). Psychological Barriers: Lurker and Poster Motivation and Behavior in Online Communities. Communications of the Association for Information Systems, 18(16):329-354.

Wo Jianzhong, Lin Chongde, Ma Hongzhong, \& Li Feng. (2001). A Study on The Development Characteristics of Adolescents' Interpersonal Relations. Psychological Development and Education, 17(3), 9-15.

Xiao Daxing, Zhang Hongxing. (2016). A Study on The Mental Health Status of Minority Nationality Students of Junior High Boarding School in The Mountainous Area. Science of Social Psychology, (9):34-39. 
Yao Jihai, Tang Dan. (2005). The Characteristics of Teacher-Student Relationship in Middle And High School: Structure, Pattern And Development. Studies of Psychology and Behavior, 3(04):275-280.

Zeng Rong, Zhang Chong, Zou Hong. (2010). On the Characteristics of High School Students' Interpersonal Relationships at School and Their Relations with Social Adaptation. Chinese Journal of Special Education, (12), 74-79.

Zhang Ling. (2016). Secondary School Students' Interpersonal Relationship and Its Impact on Students' Academic Achievement: An Empirical Study Based on China Education Panel Survey. Journal of Educational Studies, 12(6):98-103.

Zhao Shuguang. (2014). A Study on Effects of Social Media: Analysis from Social Capital Perspective. Chinese Journal of Journalism \& Communication, 36(7), 146-159. 


\section{Appendices}

\section{Appendix 1: The questionnaire on the influence of social media on the interpersonal}

\section{relationship of middle school students}

Dear students:

We are from Beijing Normal University. Thank you for taking the time to fill in the questionnaire. This questionnaire is designed to investigate the influence of social media on the interpersonal relationship of middle school students. There is no standard answer. Please fill in it according to your own situation. The information collected in this survey is only for academic research. We will respect your privacy and security and will not disclose any information. Thank you for your support!

\section{Part 1: basic information:}

\section{Your gender:}
(1) Male
(2) Female

\section{Your grade:}
(1) grade 7
(2) grade 8
(3) grade 9
(4) grade 10
(5) grade 11
(6) grade 12 


\section{Part 2: The influence of social media on interpersonal relationship}

This section is a survey of the influence of using social media on you. Please select the appropriate number according to the following description. $(\mathbf{1}=$ Strongly disagree, $2=$ Disagree, $3=$ Uncertain, 4 = Agree, 5 = Strongly agree)

\begin{tabular}{|c|c|c|c|c|c|c|}
\hline Id & Title & $\begin{array}{l}\text { Strongly } \\
\text { disagree }\end{array}$ & Disagree & Uncertain & Agree & $\begin{array}{l}\text { Strongly } \\
\text { agree }\end{array}$ \\
\hline 1 & $\begin{array}{l}\text { Social media is an important way to } \\
\text { communicate with friends and know their } \\
\text { dynamics. }\end{array}$ & 1 & 2 & 3 & 4 & 5 \\
\hline 2 & $\begin{array}{l}\text { The use of social media is an important } \\
\text { way to strengthen my relationships with } \\
\text { my classmates and friends. }\end{array}$ & 1 & 2 & 3 & 4 & 5 \\
\hline 3 & $\begin{array}{l}\text { The use of social media can strengthen the } \\
\text { interpersonal relationship between me and } \\
\text { my peers. }\end{array}$ & 1 & 2 & 3 & 4 & 5 \\
\hline 4 & $\begin{array}{l}\text { Social media is an important way to } \\
\text { strengthen my relationships with my } \\
\text { teachers. }\end{array}$ & 1 & 2 & 3 & 4 & 5 \\
\hline 5 & $\begin{array}{l}\text { I use social media to communicate with } \\
\text { unfamiliar teachers. }\end{array}$ & 1 & 2 & 3 & 4 & 5 \\
\hline 6 & $\begin{array}{l}\text { I will contact strangers I know on social } \\
\text { media in real life. }\end{array}$ & 1 & 2 & 3 & 4 & 5 \\
\hline 7 & $\begin{array}{l}\text { When I'm in a low mood or in trouble, I'll } \\
\text { talk to strangers I know on social media } \\
\text { and ask for help. }\end{array}$ & 1 & 2 & 3 & 4 & 5 \\
\hline 8 & $\begin{array}{l}\text { I often use social media to express my } \\
\text { mood and life. }\end{array}$ & 1 & 2 & 3 & 4 & 5 \\
\hline 9 & $\begin{array}{l}\text { I often use social media to comment on } \\
\text { others' news and express myself. }\end{array}$ & 1 & 2 & 3 & 4 & 5 \\
\hline 10 & $\begin{array}{l}\text { I often post and present myself through } \\
\text { social media. }\end{array}$ & 1 & 2 & 3 & 4 & 5 \\
\hline 11 & $\begin{array}{l}\text { Self-presentation and self-evaluation in } \\
\text { social media will influence my behavior in } \\
\text { real life. }\end{array}$ & 1 & 2 & 3 & 4 & 5 \\
\hline 12 & $\begin{array}{l}\text { The evaluation of others in social media } \\
\text { will affect my behavior in real life. }\end{array}$ & 1 & 2 & 3 & 4 & 5 \\
\hline 13 & $\begin{array}{l}\text { The different performance of others in } \\
\text { social media and real life will affect my } \\
\text { evaluation of others. }\end{array}$ & 1 & 2 & 3 & 4 & 5 \\
\hline 14 & $\begin{array}{l}\text { The use of social media has strengthened } \\
\text { my attention to social hot spots and current } \\
\text { events. }\end{array}$ & 1 & 2 & 3 & 4 & 5 \\
\hline 15 & $\begin{array}{l}\text { I often use social media to express my } \\
\text { views on social affairs. }\end{array}$ & 1 & 2 & 3 & 4 & 5 \\
\hline 16 & $\begin{array}{l}\text { I often discuss social events with others } \\
\text { through social media. }\end{array}$ & 1 & 2 & 3 & 4 & 5 \\
\hline
\end{tabular}




\section{Appendix 2: The interview questions}

Q1: What do you think of social media?

Q2: Would you like to use social media to communicate with your students?

Q3: What do you think is the difference between social media and telephone in communication?

Q4: Do you think middle school students are willing to use social media to promote the relationship between teachers and students?

Q5: What is your expectation for middle school students to use social media to deal with the relationship between teachers and students?

Q6: What is your expectation for middle school students to use social media to deal with interpersonal relationships? 